\title{
Flows of change: dynamic water rights and water access in peri-urban Kathmandu
}

\author{
Anushiya Shrestha ${ }^{1}$, Dik Roth $^{1}$ and Deepa Joshi ${ }^{2}$
}

\begin{abstract}
Urbanization and the changing climate are increasingly influencing people's access to land and water. Changes in use of, and rights and access to, land and water are most acutely experienced in peri-urban areas. We analyze these changes in peri-urban Kathmandu, Nepal. Increasing pressures on land and growing water needs of an expanding population in Kathmandu Valley are creating new patterns of water use, water-related conflicts, and (in)securities. We use two case studies that are characteristic of these changes, with a focus on the microlevel redefinitions of, and struggles about, rights, access, and notions of legitimate water use, and what these mean for water security and water conflict in a socially and institutionally complex and dynamic environment. Our findings show that these water-related changes cause contestations and conflicts between peri-urban water users. Amid increasing competition for water, people are using new sources and technologies, searching for negotiated solutions based on local norms and rights, and co-opting other water users through cooperation to create access opportunities and avoid conflicts. Our cases show self-restraint in practices of claiming or accessing water, while avoidance of conflicts also derives from an awareness of unequal power relations between user groups, past experiences of violence used against protesters, and lack of active intervention to regulate increasing exploitation of peri-urban land and water resources.
\end{abstract}

Key Words: access; land and water use; peri-urban; property; urbanization; water-related conflicts; water rights; water security

\section{INTRODUCTION}

The world is rapidly urbanizing, and this deeply transforms places that are still rural or "peri-urban" (Leaf 2011, United Nations 2015, Friedmann 2016). The latter term refers to "the coming together and intermixing of the urban and the rural, implying the potential for the emergence of wholly new forms of social, economic, and environmental interaction that are no longer accommodated by these received categories" (Leaf 2011:528). Although peri-urban changes have long received little scientific and policy attention, the peri-urban lens is increasingly used to explore processes of "becoming urban" (Leaf 2011). Following several authors (e.g., Iaquinta and Drescher 2000, Narain and Prakash 2016), we approach the peri-urban as (peri-) urbanization processes rather than a spatially bounded type of region. This better captures its fluid and emergent character as a hybrid of "rural" and "urban," as flows of people, resources, ideals, identities, and institutions (Iaquinta and Drescher 2000, Allen 2003). Even if we use "areas," we think primarily of their dynamic character.

Major peri-urbanization issues are changes in land tenure, and overexploitation and pollution of water (Simon 2008). Water reallocations and changing flows between urban and peri-urban areas, and within the latter, may lead to contestations and conflict (Allen 2003, Butterworth et al. 2007). Another problem is how these processes, and the places shaped under their influence, are governed. Peri-urban dynamism is at loggerheads with generally static governance structures, institutions, and jurisdictional boundaries (Allen 2003, Simon 2008). Overlapping governance institutions, legal frameworks, and competing claims of authority are common, causing characteristically peri-urban "fuzziness" and conflict-proneness (Butterworth 2007, Arabindoo 2009). Yet the implications of peri-urban water insecurity for the dynamics of conflict and cooperation have hardly been explored (Narain and Prakash 2016).

We use this peri-urban focus to analyze conflicts around rights, access, and control of a resource that is fluid by nature yet often related to land or infrastructure in ways that "fix" it as property and make it follow the logic of power rather than gravity: water. Peri-urbanization around Kathmandu, capital of Nepal, involves changes in availability, allocation, use, and control of water and land for human livelihoods. With changing populations, land conversion, increasing building activities, and the emergence of more diversified livelihoods, pressures on these resources are growing. Urban water needs, demand for products from the peri-urban, and practices of waste disposal are deeply influencing water security. These processes are further compounded by the impacts of a changing climate on precipitation, temperature, and water availability (Shrestha et al. 2014, Sada et al. 2016).

In line with the Special Issue theme and focus, we present an indepth, context-specific description and analysis of waterrelated changes in peri-urban communities to gain a more empirically grounded understanding of their consequences for water access and rights, security, and conflict. The article is structured as follows: first, we clarify our conceptual-theoretical and methodological choices. Next, we briefly introduce Kathmandu Valley, its context of urbanization and policies, and the study locations. We then present two case studies on changing water flows and uses, and their implications for water security and conflict. Each case represents a key dimension of waterrelated changes: the first concerns developments around a canal irrigation system (kulo) in Dadhikot; the second looks into increasing groundwater exploitation in Jhaukhel. These are 
followed by a discussion of the findings and what they mean for future water policies.

\section{RESEARCH APPROACH, METHODS, AND CASE SELECTION}

\section{Resource-related conflict: a property and access perspective}

The study of resource conflict was long dominated by resource determinism and assumptions of linear causalities between scarcity and (violent) conflict (e.g., Homer-Dixon 1999). Also problematic was its focus on large-scale violent conflict (war), dichotomic understanding of conflict and cooperation (conflict is "bad," cooperation "good"), and simplification of the multidimensional character of "resource conflicts." Criticism from political ecologists (e.g., Peluso and Watts 2001) has initiated more nuanced approaches from a "multicausal, multilevel, and multiactor perspective" (Bavinck et al. 2014, Frerks et al. 2014), while noting the important mediating role of socio-political processes. Scarcity and conflict are not "natural" but politically and socially produced by situated actors (Frerks et al. 2014). Although still focused on large-scale violent conflicts, the arguments basically apply to other scales and manifestations of conflict as well. We use the definition of conflict by Bavinck et al. (2014:4) as "confrontations between groups or categories of people," whether violent or not.

In the study of "water conflicts" more specifically, attention shifted from "water wars" (conspicuously absent) to local water conflicts, which are abounding (Wolf 2007, Joy et al. 2008), and from the conflict-cooperation dichotomy and the assumption of their being mutually exclusive (Zeitoun et al. 2011). Further, a critical perspective of water scarcity as socially and politically produced rather than "natural," and an understanding of how scarcities are locally experienced and lived with are crucial in understanding water conflicts (Mehta 2007). Likewise, rather than assuming simple causalities and clear "drivers" of conflict, our point of departure is that (the potential for) conflict is socially produced through political choices, policies, and changing practices of land and water use, management, and control.

When researching social-environmental relationships, two major approaches are available: complex adaptive systems and socialecological resilience (e.g., Folke 2006), and social-constructivist and political ecology approaches that foreground the coconstituted character of "the natural" and "the social" in hydrosocial changes (Swyngedouw et al. 2002). The first-mentioned "systemic" approaches have been criticized from social-scientific (e.g., Brown 2014, Olsson et al. 2015, Boas and Rothe 2016) and political ecology perspectives (e.g., Taylor 2015). Taking the latter approaches as a starting point, we aim to understand peri-urban water conflicts from an interdisciplinary perspective combined with insights from political ecology (e.g., Swyngedouw et al. 2002, Budds 2009), access theory, and legal-anthropological approaches to property. The political ecology of water has stimulated critical analysis of urbanization-related water flows, their relational and spatial-scalar dimensions, and the coconstitution of technical-hydrological and social processes. It also stresses the political, conflict-sensitive, and power-laden character of such changes. Therefore, we need to research how they differentially affect water rights, access, and inclusion and exclusion of different actors.
However, this requires indepth analysis of microlevel changes in and struggles about water, how water users experience and deal with them, and the implications for water conflicts and cooperation. Access to water basically involves complex interactions between power, authority, and control, creating a conflict-prone "...'grey zone' between what people have rights to and... access to" (Sikor and Lund 2009:2). Claims are expressed mostly through a property discourse. Hence, we use the concept of property as developed in legal anthropology: rights and obligations with regard to valued goods (von Benda-Beckmann et al. 2006). Adding to this, Ribot and Peluso (2003) have theorized access as the ability to actually derive benefits from resources. These allow us to analyze in detail the often fuzzy and gradual changes in water access and rights, and their impacts on peri-urban water security. We approach "water security" as contextual, experiential, and relational, as a general frame for asking questions like: Which changes influence whose access? Who stands to gain; who is losing? Whose social networks, authority, and power count? Such questions can be answered only in the specific context in which water (in)security is experienced (Zeitoun et al. 2013).

\section{Research questions, methodology, and case selection}

Thus, we try to answer the following questions: (1) What changes are occurring in peri-urban water uses, rights, access, and water security? (2) How are these experienced by various actors? (3) What water-related conflicts are emerging and how are they socially and institutionally dealt with? Two locations were selected as cases, using two major criteria: (1) the type of conflicts must be representative of peri-urban water issues in Kathmandu Valley more generally, and (2) the type of conflicts must cover both groundwater and surface water, each of which has specific hydrosocial, property, and access characteristics. Together, these sites provide an indepth insight into the hydro-social changes around surface and groundwater, and their implications for water security. Dadhikot, the first location, highlights changes in rights and access to surface water, while Jhaukhel, the second location, illustrates problems of groundwater exploitation.

Field research was carried out by the first author in 2015 and 2016. The research was designed as an ethnographic case study (LeCompte and Schensul 2010). Case studies are most appropriate for developing concrete, practical, contextualized knowledge (Yin 2003) pertaining to specific issues. Data were gathered by "following the water": tracing and mapping water sources, following changing flows, and exploring how various actors are differently linked to, relinked with, or delinked from these sources and flows, and hence also (re-)aligning with other actors. Data collection methods included study of policy documents, informal conversations, open and semistructured indepth interviews with actors and key informants, and focus group discussions. Field observations on water-related activities (irrigation maintenance, lifting and pumping water, meetings) were crucial for understanding the on-the-ground peri-urban water dynamics. In Dadhikot, 38 informal talks and interviews, 17 open and semistructured interviews, and three focus group discussions were held with irrigators, male and female residents, inmigrants, farmers' group leaders, water suppliers, managers, entrepreneurs, teachers, local politicians, and other relevant informants. In Jhaukhel, 39 informal talks and interviews, 30 open and semistructured interviews, and three focus group discussions 
were held with similar persons, including activists, brick factory owners, water vendors, and sand miners. In addition, informal talks and interviews were held with 26 government officials for both areas.

\section{KATHMANDU VALLEY, POLICY CONTEXT, AND CASE STUDY LOCATIONS}

\section{Kathmandu Valley}

Nepal is the least urbanized country of South Asia but has the highest urbanization rate in the region. Kathmandu Valley is one of the fastest growing South Asian urban agglomerations (Muzzini and Aparicio 2013). Its population increased from 1.6 million to more than 2.5 million between 2001 and 2011 (CBS 2001, 2012). Kathmandu Valley lies in the upper Bagmati River basin, which sustains most socioeconomic activities (Babel et al. 2014). The population of the valley, growing about $4.3 \%$ annually, increased by more than $499 \%$ between 1955 and 2008 (Bhattarai and Conway 2010). The valley's built-up area increased from $2.94 \%$ in 1967 to $24.7 \%$ in 2011 (Thapa and Murayama 2009, JICA 2012), which involved rapid changes in land and water uses in areas that were predominantly rural and agricultural until recently (Haack and Rafter 2006, Thapa and Murayama 2009).

Unplanned urbanization has significantly increased water demand and uses, and reduced groundwater and surface water quality (Pandey et al. 2012, Shrestha et al. 2015). The water demand in Kathmandu Valley has reached 377 million litres per day (MLD), while supply is 120 MLD (wet season) and 73 MLD (dry season) (KUKL 2017). The possible impacts of climate change receive growing attention. The National Adaptation Programme of Action (NAPA) has ranked Kathmandu Valley among the areas most vulnerable to climate change in Nepal (MoE 2010), with possibly profound impacts on agriculture and water availability (WECS 2011). Climate change in Nepal is occurring faster than the global average (Shrestha et al. 2000, Chaulagain 2006, Baidya et al. 2008), and is probably also influencing agriculture and water in Kathmandu Valley. Further, land fragmentation due to redistributive land reform, inheritance practices, and selling is a major problem in the valley (Shrestha 2011, KVDA 2015).

\section{The policy context}

The 1992 Water Resources Act vests ownership of water in the state, which formally owns, regulates, and controls all national water resources (see Pradhan 2000). However, both in surface irrigation systems and groundwater exploitation, such formal rules often deviate from established practices, as we will show based on our cases studies in Kathmandu Valley. The Water Resources Act sets a priority order for water uses, with drinking and domestic uses being the first priority, and irrigation being the second priority. The government has set the national target of universal access to drinking water and sanitation by 2017 , and encourages the use of surface and groundwater for improving these services. The Kathmandu Valley Water Supply Management Board (KVWSMB), a government body formed in 2006, is responsible for managing water supply and sanitation services in Kathmandu Valley. While these services are limited largely to urban centers, KVWSMB has the authority to regulate groundwater use in the entire valley. It formulated the 2012 Groundwater Policy to monitor and regulate the increasing groundwater exploitation. However, implementation has been weak. Public and private groundwater use is increasing with unplanned urban expansion, while the growing urban demand, which is not satisfied by public water provision, creates among authorities an attitude characterized by discretion and nonintervention rather than strict enforcement. Kathmandu Valley Development Authority (KVDA) has drafted the longterm development strategy 2015 for Kathmandu Valley, which aims at improving urban services and discouraging unplanned urban expansion into agricultural areas, in line with the National Land Use Policy of 2012 (KVDA 2015) and national programs and policies for reducing the impacts of climate change. This requires more coordination among land, water, urban, and climate change policies and responsible organizations (NPC 2013, KVDA 2015).

\section{Dadhikot}

Dadhikot Village Development Committee ([VDC] rural administrative unit) is located $12 \mathrm{~km}$ east of Kathmandu (Fig. 1). Covering $6.27 \mathrm{~km}^{2}$, Dadhikot is a rapidly evolving peri-urban area. Annual population growth increased from 1.17\% (1981$1991)$ to $6.05 \%$ (2011). The population increased by more than $60 \%$ and the number of houses by $99 \%$ between 2001 and 2010 (CBS 2001, 2012). Agriculture is still a major livelihood for many inhabitants, with paddy as the main monsoon crop. Wheat, traditionally the main winter crop, is increasingly being replaced by vegetables. Agriculture is traditionally based on surface irrigation: Dadhikot has three so-called rajkulos (royal canals), state-recognized "traditional" canal irrigation systems, fed by Ghatte Kholo, a tributary of Hanumante River: Mahadev Khola Rajkulo, Idole Rajkulo, and Chakhu Rajkulo (Fig. 2). We focus on water-related changes in Chakhuphant, the area irrigated by Chakhu Rajkulo. Water mills for grinding grains used to be powered by the water of Ghatte Kholo. Before new technologies replaced this system, the water was stored for use by the mills and then made available for irrigation purposes.

After road improvements in the 1980s, farmers started growing vegetables and Dadhikot became a major vegetable producing area for Kathmandu Valley (Bhaktapur DDC 2002). With ongoing land conversion, Dadhikot changed into a peri-urban patchwork of agricultural fields, multistorey buildings, and more diverse economic activities. Land transactions and building have increased considerably since then. The built-up area increased by more than $250 \%$ between 1992 and 2010, and is expected to grow by about $110 \%$ between 2010 and 2030 (Sada et al. 2016). Important causes are inmigration during the Maoist insurgency (1996-2006), fragmentation through inheritance, legally mandatory land division between tillers and landowners, and sales for cash needs. Aside from outside farmers increasingly leasing in land for commercial farming, Dadhikot landowners also rent out agricultural land to brick factories that cater to the building boom in Kathmandu Valley. These changes deeply affect water availability and quality, especially with the conversion of arable land into housing plots and the growing demand for domestic water. Uttisghari, the largest drinking water supply system in Dadhikot, was started in 1995 and is expanding its services.

\section{Jhaukhel}

Jhaukhel VDC, situated in the northeastern valley about $20 \mathrm{~km}$ from Kathmandu, covers $5.41 \mathrm{~km}^{2}$ (Fig. 1). Between 2001 and 
Fig. 1. Location of study sites in Kathmandu Valley.

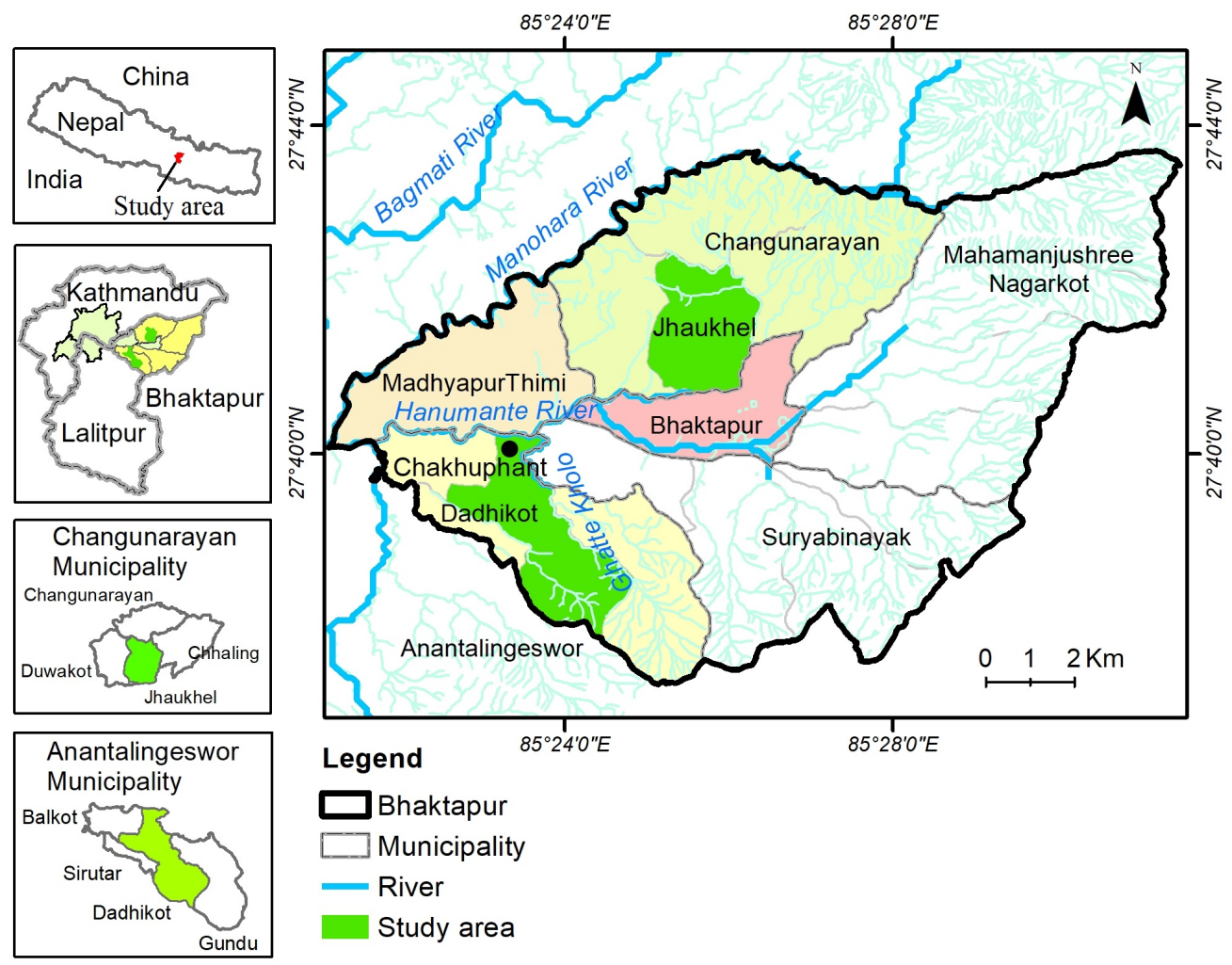

2011 , its population increased by $1.6 \%$ annually, while the builtup area increased by $3.7 \%$ annually (CBS 2001, 2012) and by more than $80 \%$ between 1992 and 2010 . The built-up area is expected to increase by more than $110 \%$ between 2010 and 2030 (Sada et al. 2016). Although livelihoods are diversifying, about $60 \%$ of the population is involved in agriculture (VDC Profile 2013). Agriculture is primarily rain-fed; paddy and maize are the main monsoon crops in the plains and on the slopes, respectively. In winter, farmers cultivate wheat, potato, vegetables, and mustard. Because Jhaukhel lacks perennial surface water sources, groundwater has become the main agricultural water source. Easier access to groundwater (pumping technology) has stimulated farmers to cultivate vegetables for urban markets and has attracted other economic activities. Brick kilns emerged in the 1990s; leasing out fields to brick factories has often replaced wheat cultivation. Jhaukhel has also become a major source of water for the adjoining Bhaktapur Municipality, where water demand is far exceeding supply. Commercial urban water supply started in the early 2000s and has continued expanding to other urban centers, both within and outside Kathmandu Valley.

We present case studies of Dadhikot and Jhaukhel to explore changes in these areas from a perspective that relates water rights and access to water security and conflict. We discuss hydro-social changes over several decades, from rural and agriculture-based toward diversifying peri-urban areas with changing populations and linkages with the urban world, and a growing diversity of land and water uses. The cases focus on different (but related) dimensions of these changes: (mainly) surface irrigation systems and other surface sources in Dadhikot, and expanding groundwater uses in Jhaukhel.

\section{DADHIKOT: COMPETING FOR RIGHTS AND ACCESS TO SURFACE WATER}

Changing users, flows, and connections

Elderly farmers in Chakhuphant share memories of the glory of Chakhu Rajkulo, one of three irrigation canals fed by Ghatte Kholo (Fig. 2). This area is called Chakhu (safe granary) locally because of its historically high paddy and wheat yields. However, according to farmers, the canal is much narrower now than before. Prior to 1990, the area was an agricultural belt where construction of houses was prohibited. The canal was managed under leadership of the local head of a village adjoining Dadhikot. The irrigation system had a central place in local life and economy. Guided by village functionaries, farmers with land in the command area of the canal made a temporary intake and voluntarily contributed cash and labor for maintenance. Until 1990, the canal was maintained twice a year, before monsoon and winter crops. However, according to farmers, water competition had already emerged from the 1970 s, when electric mills started replacing traditional water mills in Ghatte Kholo. Before this, during the dry seasons, water mill operators stored water in ponds on land rented from farmers. After use for operating the water mills, this water was drained into the canal (Fig. 2), which provided farmers with reliable year-round irrigation and equitable water distribution between Chakhuphant and other areas. As this system disappeared, water scarcity became felt. 
Fig. 2. Three rajkulos fed by Ghatte Kholo, the water structures and canal sections that existed in the past and that still exist in Chakhuphant.

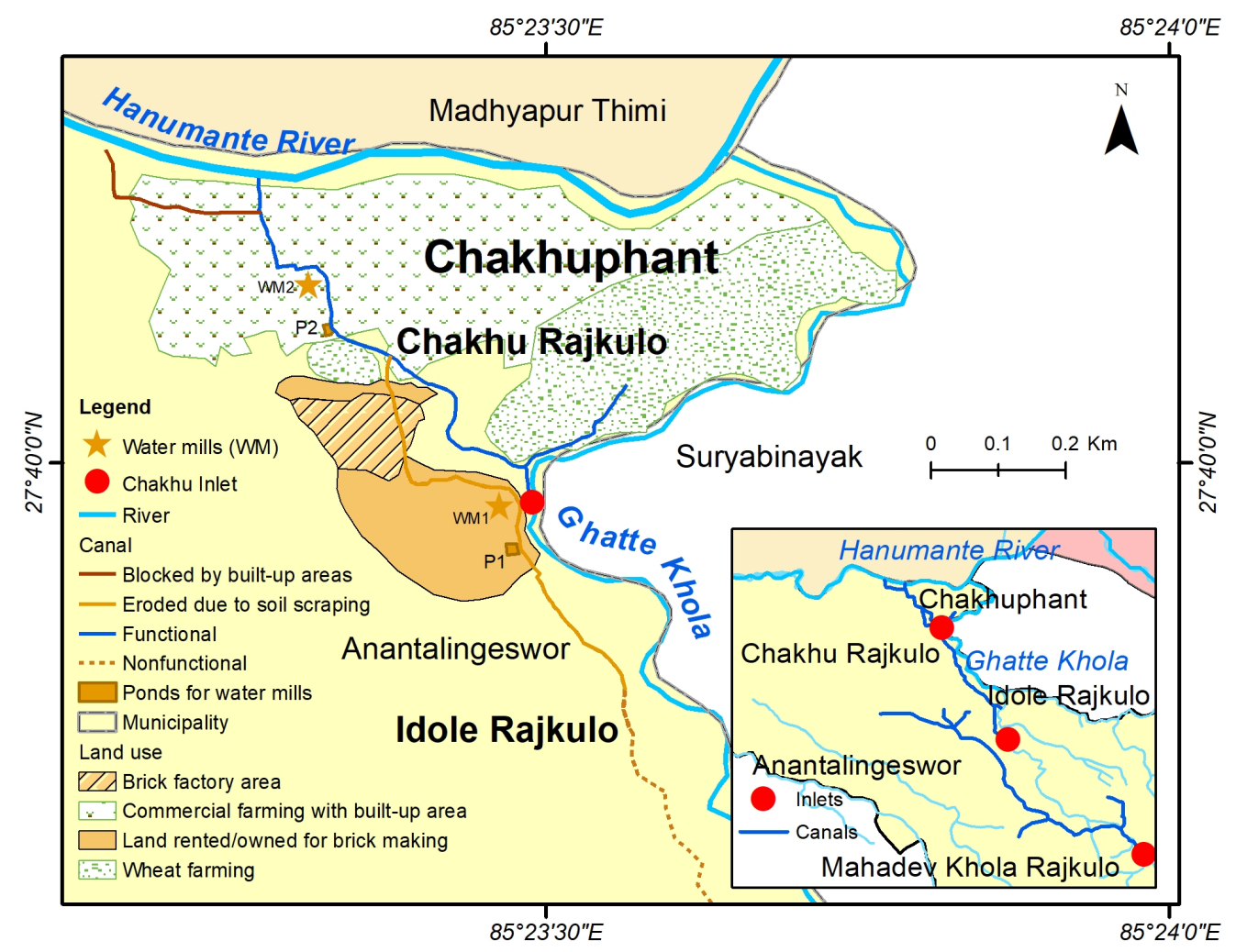

A second canal, Idole Rajkulo (Fig. 2), originates at the middle section of Ghatte Kholo and ultimately drains into Chakhu Rajkulo. However, after replacement of the water mills, access to irrigation water from Idole Rajkulo became difficult, particularly for tail-end farmers who depended on water from this canal. The tail-end fields contained many brick factories that had been established in Dadhikot in the 1980s with formal permission. Needing soil for brickmaking, they made deals with surrounding farmers. Expecting that scraping the soil would make their elevated terraces irrigable, farmers agreed to renting their fields to the factories. Soil scraping continued until the early 2000 s, but not without consequences. Due to partial erosion of Idole Rajkulo, farmers who depended on Chakhu Rajkulo were affected in two ways: reduced water supply from Idole Rajkulo (which had drained into Chakhu Rajkulo before), and growing competition for scarce water as farmers of scraped fields started accessing water from Chakhu Rajkulo, thus increasing water competition.

In addition, inmigrants who were purchasing land and building houses in the fields started extracting water from the stream and canal for construction. Houses constructed along the canal also encroached on it, reducing its capacity. Further, since 2010, brickmakers, who leased in land from farmers in the command area of the uppermost irrigation canal, have pumped water from the stream, further adding to water scarcity. In the meantime, commercial farming in Dadhikot and the upstream area where
Ghatte Kholo originates has also been drastically increasing. Upstream construction of a permanent dam and expanding commercial farming further reduced downstream water availability. Commercial farmers include both so-called "ancestral" (holding inherited land rights) landholders and new (inmigrant) farmers, leasing in land from the ancestral or inmigrant landowners. While ancestral farmers accessed canal water, land leasers accessed water directly from the stream to avoid conflicts with the former about their canal water use.

With increasing urbanization, the Uttisghari Drinking Water system, Dadhikot's largest system, started tapping a local spring in 1995. Its sump well, made in 1999-2000 to shift from public to private taps, contains seepage water tapped from Ghatte Kholo. At present, it is supplying approximately 1500 private taps, with 750 new taps being added. There are six community-managed drinking water schemes in Dadhikot, each tapping different springs. The two registered schemes, Uttisghari and Syangtyang, are also extracting groundwater through deep borewells. Similar cases occur elsewhere in the Ghatte Kholo catchment. Groundwater extraction by households and commercial farmers has also increased. An unpublished household survey conducted in 2012 showed that $27 \%$ of the households in Dadhikot extracted groundwater. Field observations show that dugwells are common among recently constructed houses. These water-related changes impact water flow in the Ghatte Kholo, which feeds water into the irrigation canals. 
Growing competition, avoiding conflicts, exploring new sources An elderly farmer has been leading canal management from the 1990s. Under his leadership, approximately 50 farmers who cultivate in Chakhuphant participate every late November in ploughing, weeding, and making a temporary water intake into Chakhu Rajkulo, using sacks filled with soil managed by the leader from the brick factory or owners of houses under construction. According to the farmer leader, "irrigating fields could be completed in a single day when the mills were still operating. To prepare for paddy transplanting we would jointly clean the canal and irrigate. I had taken the lead to make the intake for the Idole canal. Maybe thanks to that, people still look to me for canal-related activities" (farmer, Chakhuphant, 27-11-2016).

However, organizing participation in canal maintenance is not always that easy. While paddy is the main monsoon crop in Chakhuphant, in winter the ancestral farmers-particularly those with land in the lower reach-cultivate commercial vegetables. These ancestral farmers also rent in land from other ancestral landowners in winter to cultivate commercial vegetables, while ancestral farmers in the upper reach have continued cultivating wheat. Unlike wheat farming, vegetable farming needs regular irrigation. This need of irrigating the commercial vegetable winter crop could explain the fact that the ancestral farmers in the lower reach continued canal maintenance for the winter season, while those cultivating wheat in the upper reach refrained from participating in maintenance.

There was also growing competition with the nearby brick factory, which accessed water from the stream in which Chakhuphant farmers had made their temporary intake. While the factory owners had earlier rented land to store stream water, gradually they bought much of this land along the stream bank. Having land ownership, the factory fixed a large pump and pipes to transfer stream water to the factory. Importantly, the factory continued accessing water without claiming water rights to avoid conflicts with prior rightholders whose access became increasingly difficult with erosion of the Idole canal section due to soil scraping. Inmigrants also increasingly accessed water from the stream and the canal, both for house construction and, later, for domestic water. Competition for stream water has been steadily growing with the increasing use of electric pumps. An ancestral farmer: "As they lift using pumps, only little water enters the canal. It seems that, once water is in the canal, the inmigrants consider we have the right to water. So they lift water from the stream and argue: 'Can't we even lift stream water?" (farmer, Chakhuphant, 24-02-2016). Thus, while ancestral farmers base their water rights on customary claims of canal water, inmigrants access water by pumping from the stream, or from dugwells based on their land ownership. Furthermore, awareness of people's water needs and the fact that all are in the same boat struggling to access water play a role in avoiding water conflicts.

Despite their management efforts, access to canal water has been declining for rightholding farmers. A farmer: "We have been struggling for twenty-five years. But water does not come for a prolonged period, only until early January. After that, water does not reach the canal. In the past there was enough to irrigate all fields. Nowadays, people are pumping water everywhere, so we have to use water from Hanumante River" (farmer, Chakhuphant, 14-11-2015). This started in the 1970s as the quantity of water in
Ghatte Kholo decreased. With urbanization, water quality in Hanumante River degraded due to a lack of sewerage treatment (Sada 2010). However, by the late 1990s, farmers in Chakhuphant were irrigating largely from this river, using the new technology of fuel pumps. Hanumante, which used to be dry in April and May, now carries water year-round. Although this is largely wastewater, Hanumante has become the main irrigation water source for Chakhuphant farmers, both for paddy and vegetables. Farmers have their own diesel pumps and pipes, or rent them from others. Irrigating land, therefore, increasingly requires resources: money, diesel, a pump, and several meters of pipes, but especially social networks to arrange these.

Irrigating from Hanumante is not, however, a panacea. Although farmers do not see great difference in their paddy yields, they shared that irrigating from the river damages leafy vegetables. Some landowning farmers have shifted to groundwater extraction through dugwells, but most farmers chose to irrigate from Hanumante less frequently or in the early morning or evening because otherwise it "kills" most of the green vegetable saplings. Tenant farmers, whose access to land is controlled by owners, have no right to make changes in land or water use. For them, Hanumante remains the only alternative source but is increasingly also polluted by sewage from inmigrant settlements, which is causing another conflict with the Chakhuphant farmers. Similar conflicts arose after seepage of water from the irrigation canal into the sewer line that was laid out by inmigrants reduced water flow in the canal from which the farmers with ancestral rights accessed water.

\section{Changing irrigation turns, tensions about maintenance}

By 2000, use of the irrigation canal had already been limited to winter crops. However, the farmers' group from Chakhuphant commonly participated in annual canal maintenance. All ancestral farmers had a right to canal water. A basic rule for distribution was, who comes first irrigates first with half of the share; latecomers divide the other half. Nonetheless, farmers were flexible in sharing irrigation turns according to needs and availability. A farmer: "We discuss and cooperate [in the group]. If there is good flow, we share among three or four users; otherwise single users will take turns. We try to avoid quarrels in the group." However, with growing competition for water and conflicts about participation in canal cleaning, things have changed. According to the farmer leader, simple turn-by-turn irrigation, starting from the head reach and then into the lower reach is no longer accepted: "Now we give an irrigation turn first to those who maintain the canal. Is it correct to give water first to those who do not work but whose fields are in the head reach?" (farmer leader, Chakhuphant, 27-11-2016).

This suggests that increased water competition made access for prior rightholders difficult and disturbed the location-based irrigation turns. As participation declined, the farmers' group started collecting cash contributions from irrigators who do not contribute labor. Only those riparian ancestral farmers who contribute cash or labor have the right to use water. However, there are free riders: "The canal is as public as the king. There isn't anyone who does not irrigate from it." Further, contributing to maintenance does not ensure access to water. Farmers in the lower reach of Chakhuphant blame those in the upper reach of Chakhu Rajkulo for "shamelessly" using canal water, without 
contributing labor, to irrigate "land that is not even theirs." Land in this upper reach belongs to ancestral farmers who have refrained from participating in canal cleaning since the 1990s. Many of them cultivate rice in the monsoon season, and-afraid of leaving the land unused-in the winter season, they invite farmers from the adjoining village to cultivate wheat on their land, without demanding a cash or crop share. These farmers divert half the water share from Chakhu Rajkulo into "their" (branch) canal and irrigate "the land that is not even theirs." They base this practice on the ancestral farmers' rights, without, however, participating in canal cleaning. To avoid confrontation, these farmers irrigate a few weeks after those from Chakhuphant. Farmers from the lower reach critically commented: "The struggle is ours while they just take the water."

Increasing competition for canal water has reduced farmers' flexibility in sharing water. Farmers with fields far from the canal do not contribute to maintenance, as physical access to canal water is uncertain. Hence, they also avoid using water from the canal, even when it is available, to avoid "bitter words" from their fellow farmers who do contribute labor. Farmers whose adjoining fields have been converted into houses often cannot use canal water either, even when available. Lacking drainage, canal water waterlogs their fields and damages crops. Thus, without having conflicts, these farmers do not participate in management, and irrigate from Hanumante.

Thus, the area irrigated from Hanumante has increased, while availability of canal water has declined. The canal depends on stream flow, and the stream depends on rainwater. The latter, according to farmers, has considerably decreased while the number of diversions has been increasing, thus reducing the flow reaching the canal intake. Notwithstanding this trend of growing canal water scarcity, according to farmers, the number of conflicts has decreased compared to the past, when the canal was guarded at night. This can be explained by the fact that Hanumante River became an alternative water source.

\section{JHAUKHEL: INCREASING GROUNDWATER DEPENDENCY}

\section{Growing importance of groundwater}

With only seasonal streams providing water after the monsoon, stone spouts, wells, community shallow wells $(k u w a)$, and ponds were the main water sources in Jhaukhel. Managing daily water needs was difficult, particularly in the dry season. Wells were used but quickly ran dry; private dugwells emerged during the 1980s. In the 1990s, the emergence of brick kilns brought more changes in land and water use and access. Brick factories mostly rented land in winter, and returned it for monsoon cropping. On rented land, the factories started scraping soil and extracting groundwater via borewells for brickmaking. This new technology also stimulated local residents to extract groundwater for domestic and other uses. A commercial farmer: "There was no irrigation. We used to conserve water overflowing from wells and reused water after washing and bathing for irrigation. People could cultivate paddy but irrigating was difficult, so all started making borewells" (farmer, Jhaukhel, 31-12-2015).

A piped drinking water supply system started functioning in 1993 and extended its service to households through a metered tap connection by 1994 . With increasing settlement, water demands rose while supply turned irregular. Over the years, communitymanaged drinking water systems emerged and expanded in various hamlets. Shrestha et al. (2013) found 11 such systems in Jhaukhel, while this study shows a further (unregistered) increase. Settlement increased from the mid-1990s, and agricultural fields and sand-mined land were converted into residential plots. In the early 2000s, Jhaukhel had changed from a rain-dependent agricultural village into one with diverse land and water uses based on groundwater. Commercial urban water supply from Jhaukhel started in 2001, after which the number of water bottling factories rapidly increased; Jhaukhel now harbors 14 such factories. Additionally, unregistered water vendors started selling "raw water" to tankers and tractors that cater to urban water needs. A vendor: "I had a dugwell for drinking water and other needs, and made a living from farming. When we saw others selling water, we thought we should also try this. We drilled our first borewell and started selling water six years ago" (water vendor, Jhaukhel, 23-12-2015).

\section{Claiming and negotiating rights and access to land and water}

Until land sales for residential use started, land in Jhaukhel was owned largely by people from nearby Bhaktapur. This land ownership influenced land and water use in Jhaukhel. A brick factory owner: "We started renting about 40 ropanies $(1$ ropani $=$ $508.74 \mathrm{~m}^{2}$ ) of land. Landowners were mostly friends from Bhaktapur. This year we use 300 ropanies, of which we own less than $15 \%$, all other land is rented" (factory owner, Jhaukhel, 26-04-2016). Farmers who lack irrigation water often willingly rent out their land, and see it improve: "We used to plant maize on the slope, but rented the land to brick factories two decades back. Since fifteen years we have been planting paddy" (farmer, Jhaukhel, 17-12-2015). The rent is often higher than the net income from cultivation. Brick factories also have to prepare the rented land for farmers to cultivate paddy. In case of delayed monsoon rain, they also provide irrigation water. Thus, while factories gain access to land through renting, landowners can continue benefiting from their land. However, they do not always have a choice. A man renting out his land: "Brick factory owners ask landowners. If they refuse, they are not compelled but their land will become a useless elevated plot with low paddy yields. That compels farmers to rent out land to the factories, which again influences adjoining land" (landowner, Jhaukhel, 15-02-2015). This shows that land ownership does not always guarantee the owner's benefit from it, while brick factories, which do not own land, gain access and even determine what surrounding farmers can do with their land.

Access to land is also crucial for gaining access to water. Although ownership of water is formally vested in the state, in practice, access to land is widely accepted as giving a right to water. Landowners have a right to groundwater use based on their land right. An old farmer who purchases water for his household needs: "Some buy half a ropani of land and make a borewell. In some areas with borewells, people contract out the land for profit at a specific rate per month" (farmer, Jhaukhel, 01-04-2016). While purchasing land provides unlimited rights (to use, sell, or rent out land and water), renting land provides land control and water rights for a specified period. As this shows, changes in the right to land also changes the right to (ground)water. 
Water rights are also claimed on the basis of government registration. A bottling factory owner: "We do not operate without permission, we have registered our industry and have a permit. As a rule water cannot be sold without certificate. We renew it annually and pay the government tax. Moreover, we do not consume all water but also provide it to the locals. We give it for free to those who cannot afford purchasing it" (factory owner, Jhaukhel,18-03-2016). The Groundwater Policy of 2012 (and related guidelines, 2014) aims to restrict use of shallow groundwater (within $98 \mathrm{ft}[30 \mathrm{~m}]$ ) to domestic uses. A permit from KVWSMB is required for the use of deep aquifers. Water factories in Jhaukhel are registered by the Department of Cottage and Small Industries. This practice has been continued, using the argument that the water factories started operating before KVWSMB was established. The Kathmandu Valley Water Supply Management Board admitted in an interview that, contradicting the groundwater policy, shallow aquifers are commercially used. Nonetheless, KVWSMB limits its interventions because commercial water suppliers are important in filling the increasing gaps between urban water demand and supplies. Thus, commercial water users gain legal access to water through overlapping and weak government registration. They also supply water to local people, mainly as a strategy to avoid resistance and secure continued access. Unregistered water vendors, from which the municipality collects road tax, are commonly said to be illegal. However, with or without an extraction permit, the common perception is that the right to groundwater comes with the right to land, either by permanent or temporary land control.

Those without a well are weakest in accessing water: They depend on commercial users and those who own a well. A woman with unirrigated land next to her neighbor's irrigated land: "The brick factory owner installed the borewell on my neighbor's land, from which my neighbor irrigates. When we need to irrigate, they give us a little water, but everything depends on how we behave [towards them]" (female farmer, Jhaukhel, 21-1-2016). Dependency on commercial users for water compels others, including landowners, to maintain good social relations with the former. Similar problems can be seen in access to water for domestic uses, the burden of which falls mainly upon women. A Jhaukhel woman: "We had drilled a borewell for household use early 1990s, but it dried after ten years. We had a new borewell drilled but it also quickly dried. Since then we are fetching water from water factories. Even if these factory people hesitate and shout at us, we do not have other options. It is mostly women who do this job. If we do not succeed at one factory we try another. Sometimes we return empty-handed or with water that turns yellow in a day, they are reluctant to give filtered water. It is very difficult to get water. What shall we do if it dries up in the future? It will be difficult even to get drinking water" (Jhaukhel, women fetching water from a factory, 26-04-2016).

\section{Protest, power, and the avoidance of conflicts}

With declining traditional water sources and the groundwater table, making deeper wells is common practice. A well user: "We used to get water from a stone spout near our house. After that source had dried, I installed a hand pump. People all around also started making borewells as water sources were drying. Water could be accessed everywhere at around 40-50 feet. Until the late-1990s well water was good, but then it started declining.
Around 2005, when the bigger factories had come and the well dried, I made a new well, 100 feet deep. For about eight years the water level was very good, but now there is no water even at 100 feet. People go to 130-140 feet now. The deeper we go, the worse the water quality, with a high iron content" (well user, Jhaukhel, 15-02-2016). Such developments make people more critical of commercial water exploitation. In 2009, residents demonstrated at the VDC office, demanding a stop to water sales. A woman fetching water from a "raw water" seller: "As water sources dried, people demonstrated at the VDC. We demanded that water selling should not be permitted. Then the VDC said that, except for registered factories, water sales will not be allowed, but later they did not follow that. This created animosity between vendors and protesters. The water sellers said that we are jealous of them. From then they hesitated even more to give us water. Those who raise their voices are considered enemies" (water user, Jhaukhel, 26-04-2016).

Although groundwater depletion and deterioration of water quality have increased, open opposition has remained rare. This can be related to an earlier event: Jhaukhel residents had encountered violent conflict in 2002, when a campaign against the brick factories, organized by a group of environmentally proactive local residents to sensitize villagers not to lease out their lands, turned violent. Leaving some injured, this conflict made residents avoid open conflicts until today. Other issues play a role as well: protests often create antagonisms with friends and relatives involved in these businesses. Hence, people seldom report or oppose such practices: "Even if we are suffering, we do not raise our voices. To reciprocate, water vendors allow neighbors to take water for free. They say 'take as much water as you need, why bother if your water source has dried.' That is how they operate" (farmer, Jhaukhel, 17-12-2015).

Women often bear the burden of fetching water from the few functional water sources, taps, or vendors. A woman whose wells had dried: "Mostly people fetch water in the water factories, often by quarrelling. We say: 'You have water for sale but do not give us some for drinking?' Sometimes we return empty-handed, sometimes we fill our buckets. What else can we do? When water is extracted in such intensive competition, it will definitely run dry in the future" (woman, Jhaukhel, 26-04-2016). This shows the daily struggles for water: although local residents have a right to domestic water, actually accessing it is difficult and requires courage. With loss of access, farmers also lost potential livelihood options in agriculture. Some wells installed for irrigation came to be used exclusively for drinking water, as traditional sources dried up. A woman leading a farmers' group: "For water, it is not appropriate to exclude those not belonging to the group. We acquired and have the right to use these wells for irrigation, but they [drinking water users] do not let us do so" (group discussion, Jhaukhel, 05-10-2015).

\section{DISCUSSION}

We have investigated changing water uses and water security in two communities in Kathmandu Valley-Dadhikot and Jhaukhel, explored how these changes are experienced by various actors, and looked into the role of conflict and cooperation in dealing with them. The cases show that peri-urbanization brings advantages and opportunities for some (commercial farming, water vending, brickmaking), often at the expense of others 
(ancestral farmers, groundwater-dependent Jhaukhel citizens). The cases abound with examples of growing water insecurity. However, the overall picture of benefits and disadvantages is rather fuzzy: a brick factory, for instance, may provide benefits to surrounding farmers but also cause long-term damages (pollution, disturbance of groundwater, canal erosion). One thing is clear: with increasing peri-urban water insecurity, the incidence of contestations and conflicts may also increase. Changing ways of accessing water, based on claims (e.g., traditional residents' rights as inhabitants, water factories with government registration) or otherwise (unregistered water vendors, brick factories) are further driving changes in peri-urban land and water uses and thus increasing water insecurity and conflicts. Fuzzy as these processes may be, women tend to bear much of the burden. They are often responsible for managing domestic water needs. In Jhaukhel, for instance, access to groundwater has become difficult for households that depend on shallow wells or spouts, which has added to the workload of women. Aside from this, these hydro-social changes are too complex to clearly distinguish winners from losers and culprits from victims.

However, some key issues in negotiating, claiming, and denying water rights and water use can be discerned, around which waterrelated conflicts easily develop. First, the relative positions of water inlet structures of canals and locations of farmers' land in command areas and along canals (head, middle, or tail-end positions; close to the canal or at greater distance) are increasingly important determinants of access to surface water. Second, the origin of farmers (ancestral or inmigrant) is often used normatively in relation to statements about water rights, water use practices, and problems of water insecurity. Third, issues of (non)participation in canal maintenance, often related to local notions of good behavior and justice, seem to be the only nonnegotiable. People should participate, pay, or otherwise abstain from taking water to avoid moral indignation and exclusion. Fourth, issues of different sources and uses of water (e.g., irrigation of commercial crops and canal water use; commercial groundwater use and its environmental consequences) are sensitive and may lead to conflicts. Often these issues are framed and perceived as interconnected, such as participation in canal maintenance and farmers' origin, or seasonal cropping practices in relation to location and participation in maintenance. In this complex hydro-social landscape, negotiations about water rights and access for rightholders are increasingly difficult, both for surface water and groundwater.

\section{Continuity and change in water rights and access}

How are these water security issues related to changing water rights and access? Growing water competition in Chakhuphant (Dadhikot) is distorting customary water rights and allocation in surface irrigation canals. Ancestral farmers, the prior rightholders, are gradually loosing access to water and are no longer able to materialize their rights (see Roth et al. 2005). This compels them to use polluted stream water to avoid conflicts about scarce canal water. Irrigation turns are becoming less flexible as rights-related responsibilities are less adhered to. On the other hand, the case shows that customary notions of water rights as inseparable "bundles" of rights, and obligations are, to some extent, still respected by ancestral farmers and even inmigrants, and continue to structure irrigation practices. In Jhaukhel, groundwater emerged as a new water source, initially based on shallow aquifers but gradually moving into deep aquifers as well. Historically, the right to use groundwater has been strongly associated with land rights, either through ownership or other arrangements. Although this strongly established notion of legitimacy of groundwater use is increasingly circumscribed by restrictive policies and regulations, in Kathmandu Valley, these are not strictly enforced. Commercial water vendors have become powerful actors, crucial for filling the gaps between urban water demand and public provision, and hence benefit from the discretionary powers of responsible agencies.

The relatively recently introduced pumping technology is deeply influencing surface and groundwater uses. Where rights-based forms of access are weakening or disappearing, pumping technology creates new options for accessing water on an ad-hoc and highly individualized basis. Pumping from surface canals and streams has become a new solution to water scarcities. Although these practices create new contestations about their legitimacy (pumping canal water impinges on the canal water rights of ancestral farmers; pumping from a stream feeding irrigation canals has an impact on water availability for downstream canals), they also contribute to the temporary alleviation of scarcity; an example is pumping water from the heavily polluted Hanumante River. In groundwater, pumping technology brought a temporary relief from the water insecurity caused by seasonal drying up of shallow wells, spouts, and springs. However, this relief was shortlived, as increasing exploitation for urban demands (e.g., water vending) worsened groundwater problems, and even excluded rightholders from their access to water. Large-scale groundwater exploitation has now become a major conflict-sensitive issue in Jhaukhel.

Because groundwater use requires material and other resources commanded primarily by well-to-do people like water entrepreneurs, it may have an exclusionary effect on poor groups. Peri-urban rightholders, for instance, often become dependent on nonrightholders for access to water. After drying up of their water sources, Jhaukhel residents depend on water vendors, despite the fact that the former have water rights and the latter's practices are illegal. This shows that water access is not always rights-based, nor do rights always ensure access (see Ribot and Peluso 2003). Notwithstanding the existence of a governmental permit system for commercial exploitation of deep aquifers and a prohibition of commercial exploitation of shallow ones, transgressions of both are tolerated because of the urgency of urban water provision. Restrictions on groundwater exploitation are further complicated by the fact that groundwater exploitation is still widely regarded as legitimate for those who control the land, even though overexploitation may lead to loss of public access to water spouts and other sources like shallow wells.

\section{Avoiding conflicts, co-opting farmers and households, suppressing protests}

Water use in this "grey zone" between rights and access (Sikor and Lund 2009) to peri-urban water is conflict-sensitive. Where government authorities do not actively intervene to regulate commercial exploitation like water vending and brickmaking, and seem to tolerate or even support these activities, tensions may run high. When the local government did not forbid water selling in Jhaukhel, tensions increased considerably, and when citizens protested against the pollution caused by brick factories, violence 
broke out. In view of the key importance of water, however, there are remarkably few conflicts that actually escalate into physical violence. Our cases show several mechanisms that, together, provide an explanation for this: flexibility and awareness of local norms and rights; co-option through cooperation and mutual benefits; and conflict avoidance, power relations, and dependence.

\section{Flexibility and awareness of local norms and rights}

Realization that water access problems are experienced by many creates a degree of tolerance toward other people's water accessing behavior. As in Jhaukhel, where a well constructed for irrigation came to be fully used for drinking water, this attitude may be further strengthened by shared norms about the inappropriateness of denying people access to drinking water. Several other examples of awareness of local norms and rules emerge from the case studies. First, inmigrants leasing land in Dadhikot show awareness of local water accessing norms by taking water from a stream, regarded as public property, rather than from an irrigation canal, to which water rights are attached. The same goes for brick factories in Chakhuphant that pump stream water rather than use canal water. Further, rightholding farmers whose access to irrigation water has become uncertain, and who hence no longer join maintenance, also abstain from using canal water to avoid conflicts about free-riding. Third, although farmers in upper Chakhu Rajkulo, invited in the winter season to cultivate wheat, are using irrigation water without participating in maintenance, they at least postpone irrigation to avoid confrontations.

\section{Co-option through cooperation and the creation of mutual benefits}

Entrepreneurs in both areas are dependent on local people in many ways. They can do business (water vending, brickmaking) only if the local population at least tolerates - but even better, actively supports - their activities, allows them access to land and water, and is willing to cooperate in other ways (e.g., by providing labor opportunities). Hence, they have a clear interest in increasing the legitimacy of their operations by providing support and seeking forms of cooperation that make their presence look like a win-win situation. Both cases show how brick factory owners make deals with surrounding farmers. In Jhaukhel, the factories rent land and scrape and level it for another cropping season, and provide irrigation water. In the short term, farmers benefit from such services, but the long-term consequences may be less beneficial: canal erosion, more water scarcity, and competition in Dadhikot; pollution, lowering of the groundwater level, and no option for landowners but to accept cooperation with the factories in Jhaukhel. Similarly, commercial water vendors provide limited access to their water for surrounding households, provided that they "behave." Labor opportunities further strengthen the networks of local support by creating loyalties to the enterprise among laborers and their relatives. Such deals, which create mutual benefits, make people increasingly dependent on and supportive of the activities of commercial enterprises, thus silencing critical voices.

\section{Conflict avoidance, power relations, and dependence}

Fear of conflicts may make people explore alternative water sources. Aided by pumping technology, irrigating from Hanumante River in Dadhikot became such a solution for farmers who did not want to compete for scarce canal water and can mobilize the resources needed for pumping. Even though forced by growing scarcity and competition, these farmers have a degree of choice. Others are less fortunate because of their dependence on water providers. Thus, for households in Jhaukhel that depend on commercial water vendors or brick factories for their water, maintaining good social relationships with the provider is crucial. In such situations, criticism of commercial entrepreneurs may endanger the continuity of their access. Since the violence in Jhaukhel, there is widespread fear of protesting or campaigning against brick factories and water entrepreneurs, powerful groups whose interests even find support in government circles. Likewise, fear of disturbing social networks of relatives and neighborhoods explains people's restraint in openly contesting and opposing commercial extraction practices.

Even though the first of these mechanisms may be based on power relations that maintain a property status quo in society, it is important in preventing conflicts from developing by behavioral choices of water users. The second one, on the other hand, coopts water users into the agendas of commercial exploiters, which may postpone or dampen conflicts but will probably not solve them. The third one is ultimately based on fear of social conflicts, the exertion of power and threat of violence, and might well raise tensions in the long run.

\section{Implications for dealing with water conflicts}

Our analysis shows the importance of indepth research on changing water security, conflict, and cooperation in specific socio-environmental contexts. While it is clear that in a situation of growing scarcity and water insecurity, the potential for conflicts also increases, these changes cannot be understood from a linear causal scarcity-conflict perspective, as suggested in earlier work (e.g., Homer-Dixon 1999). Water scarcity and insecurity are socially produced in the multiple changes taking place around both surface water flows and groundwater (see e.g., Mehta 2007, Zeitoun et al. 2013). The same goes for water-related conflicts and the various ways in which such conflicts are expressed, managed, dampened, avoided, or suppressed, including through forms of cooperation. Understanding these processes, mechanisms, and dependencies concerning water scarcity and (in)security is imperative in understanding peri-urban dynamics of conflicts and cooperation.

Our focus on property and access proves to be indispensable for really understanding the sociality of the changing water flows that we analyzed. Placing a hyphen between "the hydro" and "the social" explains nothing in itself, but is given deeper meaning by looking into the changing practices of claiming and accessing water in a setting characterized by institutional complexity, multiple competing authorities, and shifting powers. The changing ways of claiming and accessing water and land crucially involve conflicts, contestations, and negotiations. While formerly relatively clear water rights associated with surface irrigation canals are weakening, access to water is increasingly shaped by access to technology, social networks, power, and capital. Periurbanization has distorted traditional water use practices and introduced new ones but has also created new divisions and disparities between various water users. It provides opportunities for some but has specifically increased water access problems for the poor, who are often dependent on those with access to land and water. With ongoing urbanization in the context of a changing climate, the local water conflict potential will probably increase. 
In view of this, developing more conflict-sensitive ways of governing peri-urban resources should be a priority of scientists and policy-makers. Understanding the complex institutional and regulatory landscape through which water is currently governed is highly relevant in estimating future options for peri-urban water governance. Currently, urbanization is a largely unplanned and uncontrolled process. When changes in water rights, access, and security are concerned, state agencies are mainly muddling through processes that they cannot-or least do not-fully control (e.g., Dadhikot: canal irrigation; Jhaukhel: commercial groundwater exploitation). As can be seen in surface irrigation canals (Dadhikot) and the local norms of groundwater use (Jhaukhel), water is also governed through nonstate institutions. In this peri-urban context of multiple, partly ineffective, governance arrangements, the danger of conflict is very real.

Urbanization is likely to worsen peri-urban water competition and conflicts, despite ongoing efforts to augment urban water supply (Domènech et al. 2013). For lack of basic water supply services, many peri-urban residents depend on those who are exploiting peri-urban resources commercially, even if such exploitation increases water insecurities. This growing gap between those who are able to create, maintain, and expand access to water for commercial purposes and those who are missing or losing that access, lays bare the basically political character of water distribution and allocation in a context of growing scarcity caused by uncontrolled changes in peri-urban land and water uses. Clear long-term priorities will have to be set and acted upon by governing bodies that are responsible for regulating land and water uses and providing water services. Peri-urban areas need specific attention because of the extremely rapid socioenvironmental changes taking place there and the multiple statebased and other regulatory institutions and arrangements that play a role in water provision. In addition to the improvement of basic water services by political priority-setting in a context of growing scarcities, a much neglected yet crucial contribution to water security is to ensure that water users, service providers, and those affecting water sources (sand miners, polluting industries) contribute to water conservation (e.g., rainwater harvesting and recharge, wastewater treatment), both in quality and quality. These could help address growing concerns about peri-urban water insecurity and water conflicts.

Responses to this article can be read online at: http://www.ecologyandsociety.org/issues/responses. php/10085

\section{Acknowledgments:}

Research for this paper was part of the project 'Climate Policy, Conflicts and Cooperation in Peri-Urban South Asia. Towards Resilient and Water Secure Communities,' in the framework of the program 'Conflict and Cooperation in the Management of Climate Change,' (CCMCC) funded by NWO (Netherlands Organisation for Scientific Research) and DFID (UK Department For International Development). We thank Dibesh Shrestha for preparing the maps, and all our informants for giving their time and sharing their experiences, without which we would not have been able to bring forward the complex peri-urban water dynamics.

\section{LITERATURE CITED}

Allen, A. 2003. Environmental planning and management of the peri-urban interface: perspectives on an emerging field. Environment and Urbanization 15:135-147. http://dx.doi. org/10.1177/095624780301500103

Arabindoo, P. 2009. Falling apart at the margins? Neighbourhood transformations in peri-urban Chennai. Development and Change 40(5):879-901. http://dx.doi.org/10.1111/j.1467-7660.2009.01587. $\underline{x}$

Babel, M. S., S. P. Bhusal, S. M. Wahid, and A. Agarwal. 2014. Climate change and water resources in the Bagmati River Basin, Nepal. Theoretical and Applied Climatology 115(3):639-654. http://dx.doi.org/10.1007/s00704-013-0910-4

Baidya, S. K., M. L. Shrestha, and M. M. Sheikh. 2008. Trends in daily climatic extremes of temperature and rainfall in Nepal. Journal of Hydrology and Meteorology 5:38-51.

Bavinck, M., L. Pellegrini, and E. Mostert, editors. 2014. Conflicts over natural resources in the global South: conceptual approaches. CRC Press, Boca Raton, Florida, USA.

Bhaktapur District Development Committee (DDC). 2002. Periodic district development plan Bhaktapur (2002/03-2006/07) district profile analysis. Part-1. Bhaktapur DDC, Bhaktapur, Nepal.

Bhattarai, K., and D. Conway. 2010. Urban vulnerabilities in the Kathmandu Valley, Nepal: visualizations of human/hazard interactions. Journal of Geographic Information System 2:63-84. http://dx.doi.org/10.4236/jgis.2010.22012

Boas, I., and D. Rothe. 2016. From conflict to resilience? Explaining recent changes in climate security discourse and practice. Environmental Politics 25(4):613-632. http://dx.doi. org/10.1080/09644016.2016.1160479

Brown, K. 2014. Global environmental change I: a social turn for resilience? Progress in Human Geography 38(1):107-117. http://dx. doi.org/10.1177/0309132513498837

Budds, J. 2009. Contested $\mathrm{H}_{2} \mathrm{O}$ : science, policy and politics in water resources management in Chile. Geoforum 40:418-430. http://dx.doi.org/10.1016/j.geoforum.2008.12.008

Butterworth, J., R. Ducrot, N. Faysse, and S. Janakarajan, editors. 2007. Peri-urban water conflicts: supporting dialogue and negotiation. Technical Paper Series: No. 50. IRC International Water and Sanitation Centre, Delft, The Netherlands.

Central Bureau of Statistics (CBS). 2001. Statistical year book of Nepal. HMG, Nepal.

Central Bureau of Statistics (CBS). 2012. National population and housing census (Village development committeel municipality). Government of Nepal, Kathmandu, Nepal.

Chaulagain, N. P. 2006. Impacts of climate change on water resources of Nepal: the physical and socioeconomic dimensions. Thesis. University of Flensburg, Flensburg, Germany. http://dx. doi.org/10.1088/1755-1307/6/29/292029

Domènech, L., H. March, and D. Sauri. 2013. Contesting largescale water supply projects at both ends of the pipe in Kathmandu 
and Melamchi Valleys, Nepal. Geoforum 47:22-31. http://dx.doi. org/10.1016/j.geoforum.2013.02.002

Folke, C. 2006. Resilience: the emergence of a perspective for social-ecological systems analysis. Global Environmental Change 16:253-267. http://dx.doi.org/10.1016/j.gloenvcha.2006.04.002

Frerks, G., T. Dietz, and P. van der Zaag. 2014. Conflict and cooperation on natural resources: justifying the $\mathrm{CoCooN}$ programme. Pages 13-34 in M. Bavinck, L. Pellegrini, and E. Mostert, editors. Conflicts over natural resources in the global South: conceptual approaches. CRC Press, Boca Raton, Florida, USA.

Friedmann, J. 2016. The future of periurban research. Cities 53:163-165. http://dx.doi.org/10.1016/j.cities.2016.01.009

Haack, B. N., and A. Rafter. 2006. Urban growth analysis and modeling in the Kathmandu Valley, Nepal. Habitat International 30:1056-1065. http://dx.doi.org/10.1016/j.habitatint.2005.12.001

Homer-Dixon, T. F. 1999. Environment, scarcity and violence. Princeton University Press, Princeton, New Jersey, USA. http:// dx.doi.org/10.1515/9781400822997

Iaquinta, D. L., and A. W. Drescher. 2000. Defining periurban: understanding rural-urban linkages and their connection to institutional contexts. [online] URL: http://portal.geographie.unifreiburg.de/forschungsprojekte/indigenoveg/Background1PeriurbanTypology.pdf

Japan International Cooperation Agency (JICA). 2012. The Federal Democratic Republic of Nepal, Ministry of Physical Planning, Works and Transport Management Department of Roads. Data collection survey on traffic improvement in Kathmandu Valley. Final report. Nippon KOEI Co., Ltd. Eight-Japan Engineering Consultants.

Joy, K. J., B. Gujja, S. Paranjape, V. Goud, and S. Vispute, editors. 2008. Water conflicts in India. A million revolts in the making. Routledge, London, UK.

Kathmandu Upatyaka Khanepani Limited (KUKL). 2017. Annual report ninth anniversary. Kathmandu, Nepal.

Kathmandu Valley Development Authority (KVDA). 2015. Kathmandu Valley 2035 and beyond 20 years strategic development master plan (2015-2035) for Kathmandu Valley (draft). Ministry of Urban Development, Nepal.

Leaf, M. 2011. Periurban Asia: a commentary on "becoming urban”. Pacific Affairs 84(3):525-534. http://dx.doi. org/10.5509/2011843525

LeCompte, M. D., and J. J. Schensul. 2010. Designing and conducting ethnographic research: an introduction (ethnographer's toolkit, second edition). Altamira Press, USA.

Mehta, L. 2007. Whose scarcity? Whose property? The case of water in western India. Land Use Policy 24:654-663. http://dx.doi. org/10.1016/j.landusepol.2006.05.009

Ministry of Environment (MoE). 2010. National adaptation programme of action (NAPA) to climate change. Kathmandu, Nepal. [online] URL: http://unfccc.int/resource/docs/napa/ np101.pdf
Muzzini, E., and G. Aparicio. 2013. Urban growth and spatial transition in Nepal. An initial assessment. The World Bank, Washington, D.C., USA. http://dx.doi.org/10.1596/978-0-8213-9659-9

Narain, V., and A. Prakash, editors. 2016. Water security in periurban South Asia. Adapting to climate change and urbanization. Oxford University Press, New Delhi, India. http://dx.doi. org/10.1093/acprof:oso/9780199464166.001.0001

National Planning Commission (NPC). 2013. An approach paper to the thirteenth plan (FY 2013/14 - 2015/16) (unofficial translation). Government of Nepal, National Planning Commission, Singha Durbar, Kathmandu, Nepal.

Olsson, L., A. Jerneck, H. Thoren, J. Persson, and D. O'Byrne. 2015. Why resilience is unappealing to social science: theoretical and empirical investigations of the scientific use of resilience. Science Advances 1(4):e1400217. http://dx.doi.org/10.1126/ sciadv. 1400217

Pandey, V. P., S. Shrestha, and F. Kazama. 2012. Groundwater in the Kathmandu Valley: development dynamics, consequences and prospects for sustainable management. European Water 37:3-14.

Peluso, N. L., and M. Watts, editors. 2001. Violent environments. Cornell University Press, Ithaca, New York, USA.

Pradhan, R. 2000. 'Land and water rights in Nepal.' Pages 38-70 in R. Pradhan, F. von Benda-Beckmann, and K. von BendaBeckmann, editors. Water, land and law. Changing rights to land and water in Nepal. Proceedings of a workshop held in Kathmandu. Freedeal, Kathmandu, Nepal.

Ribot, J. C., and N. L. Peluso. 2003. The theory of access. Rural Sociological Society 68(2):153-181.

Roth, D., R. Boelens, and M. Zwarteveen, editors. 2005. Liquid relations. Contested water rights and legal complexity. Rutgers University Press, New Brunswick, New Jersey, USA.

Sada, R. 2010. Processes and consequences of degradation of Hanumante River: religious, cultural and livelihood impacts. Thesis. Pokhara University, Nepal Engineering College-Center for Postgraduate Studies, Pulchowk, Lalitpur.

Sada, R., A. Shukla, A. Shrestha, and L. A. Melsen. 2016. Growing urbanization, changing climate, and adaptation in periurban Kathmandu: emerging shapes of water and livelihood security. Pages 147-186 in V. Narain and A. Prakash, editors. Water security in peri-urban South Asia. Adapting to climate change and urbanization. Oxford University Press, New Delhi, India. http://dx.doi.org/10.1093/acprof:oso/9780199464166.003.0005

Shrestha, A., R. Sada, K. Karki, and A. Shukla. 2013. Groundwater extraction: implications on local water security of peri-urban, Kathmandu, Nepal. Peri-urban Water Security Discussion Paper Series No. 7. SaciWATERs.

Shrestha, A., R. Sada, and L. Melsen. 2014. Adapting to periurban water insecurity induced by urbanization and climate change. Hydro Nepal 14:43-48. http://dx.doi.org/10.3126/hn. v14i0.11259

Shrestha, A. B., C. P. Wake, J. E. Dibb, and P. A. Mayewski. 2000. Precipitation fluctuations in the Nepal Himalaya and its vicinity 
and relationship with some large scale climatological parameters. International Journal of Climatology 20:317-327. http://dx.doi. org/10.1002/(SICI)1097-0088(20000315)20:3<317::AID-JOC476>3.0. $\mathrm{CO} ; 2-\mathrm{G}$

Shrestha, B. 2011. The land development boom in Kathmandu Valley. International Land Coalition, CIRAD, College of Development Studies. [online] URL: http://www.landcoalition. org/sites/default/files/documents/resources/CDS Nepal web 11.03.11. pdf

Shrestha, N., A. Lamsal, R. K. Regmi, and B. K. Mishra. 2015. Current status of water environment in Kathmandu Valley, Nepal. Water and Urban Initiative Working Paper Series Number 03. United Nations University. [online] URL: http://collections. unu.edu/eserv/UNU:2852/WUI WP3.pdf

Sikor, T., and C. Lund. 2009. Access and property: a question of power and authority. Development and Change 40(1):1-22. http:// dx.doi.org/10.1111/j.1467-7660.2009.01503.x

Simon, D. 2008. Urban environments: issues on the peri-urban fringe. Annual Review of Environment and Resources 33:167-185. http://dx.doi.org/10.1146/annurev.environ.33.021407.093240

Swyngedouw, E., M. Kaika, and E. Castro. 2002. Urban water: a political-ecology perspective. Built Environment 28(2):124-137.

Taylor, M. 2015. The political ecology of climate change adaptation: livelihoods, agrarian change and the conflicts of development. Routledge, Oxon, and New York.

Thapa, R. B., and Y. Murayama. 2009. Examining spatiotemporal urbanization patterns in Kathmandu Valley, Nepal: remote sensing and spatial metrics approaches. Remote Sensing 1 (3):534-556. http://dx.doi.org/10.3390/rs1030534

United Nations. 2015. World urbanization prospects. The 2014 revision. Department of Economic and Social Affairs, Population Division, United Nations, New York, USA.

Village Development Committee (VDC) Profile. 2013. VDC Profile of Jhaukhel. Jhaukhel VDC.

von Benda-Beckmann, F., K. von Benda-Beckmann, and M. Wiber, editors. 2006. Changing properties of property. Berghahn, New York and Oxford.

Water and Energy Commission Secretariat (WECS). 2011. Water resources of Nepal in the context of climate change. Government of Nepal, Kathmandu, Nepal. [online] URL: http://assets.panda. org/downloads/water resources of nepal final press design.pdf

Wolf, A. T. 2007. Shared waters: conflict and cooperation. Annual Review of Environment and Resources 32:241-269. http://dx.doi. org/10.1146/annurev.energy.32.041006.101434

Yin, R. K. 2003. Case study research: design and methods. Third edition. Applied social research methods series. Volume 5. SAGE Publications International Educational and Professional, Thousand Oaks, London, New Delhi.

Zeitoun, M., N. Mirumachi, and J. Warner. 2011. Transboundary interaction II: the influence of 'soft' power. International Environmental Agreements 11:159-178. http://dx.doi.org/10.1007/ s10784-010-9134-6
Zeitoun, M., B. Lankord, K. Bakker, and D. Conway. 2013. Introduction: a battle of ideas for water security. Pages 3-10 in B. Lankford, K. Bakker, M. Zeitoun, and D. Conway, editors. Water security: principles, perspectives, practices. Routledge/Earthscan. 